\title{
Synthesis and characterization of the ionic liquid 1-methyl-3-(2,6-(S)-dimethyloct-2- ene)-imidazol tetrafluoroborate
}

Síntese e caracterização do líquido iônico 1-metil-3-(2,6-(S)-dimetilloct-2-ene)-imidazol

tetrafluoroborato

Síntesis y caracterización del líquido iónico 1-metil-3-(2,6-(S)-dimetiloct-2-ene)-imidazol

tetrafluoroborato

Received: 08/02/2021 | Reviewed: 08/06/2021 | Accept: 08/10/2021 | Published: 08/14/2021

\author{
Ângelo Anderson Silva de Oliveira \\ ORCID: https://orcid.org/0000-0002-4143-3238 \\ Federal University of Rio Grande do Norte, Brazil \\ E-mail: angelo_quimica@hotmail.com \\ Dulce Maria de Araújo Melo \\ ORCID: https://orcid.org/0000-0001-9845-2360 \\ Federal University of Rio Grande do Norte, Brazil \\ E-mail: daraujomelo@gmail.com \\ Heloísa Pimenta de Macedo \\ ORCID: https://orcid.org/0000-0002-2072-3105 \\ Federal University of Rio Grande do Norte, Brazil \\ E-mail: helo.pimenta@hotmail.com \\ Rodolfo Luiz Bezerra de Araújo Medeiros \\ ORCID: https://orcid.org/0000-0002-3072-1250 \\ Federal University of Rio Grande do Norte, Brazil \\ E-mail: rodolfoluis.eng@gmail.com \\ Ranayanne Suylane Pereira Campos \\ ORCID: https://orcid.org/0000-0002-2793-6218 \\ Federal University of Rio Grande do Norte, Brazil \\ E-mail: ranayannesuylane@gmail.com \\ Pedro Paulo Linnhares Ferreira \\ ORCID: https://orcid.org/0000-0003-3672-3641 \\ Federal University of Rio Grande do Norte, Brazil \\ E-mail: pedrolinharesf@gmail.com \\ Tomaz Rodrigues de Araújo \\ ORCID: https://orcid.org/0000-0002-5368-9775 \\ Federal University of Rio Grande do Norte, Brazil \\ E-mail: tomaz.rdaraujo@bct.ect.ufrn.br
}

\begin{abstract}
Ionic liquids (ILs) are good electrical conductors and organic liquid compounds at room temperature, with potential applicability in water electrolysis for $\mathrm{H}_{2}$ generation. The objective of this work is to describe the synthesis, characterization and study of the feasibility of ionic liquid 1-methyl-3-(2,6-(S)-dimethyloct-2-ene)-imidazolium tetrafluoroborate $\left(\mathrm{MDI}-\mathrm{BF}_{4}\right)$ as electrolyte to produce hydrogen through electrolysis of water. The synthesized MDI$\mathrm{BF}_{4}$ was characterized by thermogravimetric analysis (TGA) and differential scanning calorimetry (DSC), midinfrared spectroscopy with Fourier Transform by method of attenuated total reflectance (FTIR-ATR), nuclear magnetic resonance spectroscopy of hydrogen $\left(\mathrm{NMR}{ }^{1} \mathrm{H}\right)$ and cyclic voltammetry $(\mathrm{CV})$. The yield of the synthesis were calculate by the TGA and DSC. From the results: The infrared spectroscopy identified the functional groups of the compound and the B-F bond at $1053 \mathrm{~cm}^{-1}$. The NMR ${ }^{1} \mathrm{H}$ analyzed and compared with literature data confirms the structure of MDI-BF 4 . The yield of the synthesis of MDI-BF 4 which was $88.84 \%$. The current density achieved by $\mathrm{MDI}-\mathrm{BF}_{4}$ in the voltammogram shows that the IL can conduct electrical current regardless the concentration of water, indicating that the $\mathrm{MDI}-\mathrm{BF}_{4}$ is a potential electrolyte for hydrogen production from water electrolysis.
\end{abstract}

Keywords: Ionic liquid; Tetrafluoroborate; 1-Methylimidazole; Reaction yield; Water; Electrolysis.

\section{Resumo}

Líquidos iônicos (LIs) são bons condutores elétricos e compostos orgânicos líquidos em temperatura ambiente, com potencial aplicabilidade em eletrólise de água para geração de $\mathrm{H}_{2}$. O objetivo desse trabalho é descrever a síntese, caracterização e estudo da viabilidade do líquido iônico 1-metil-3-(2,6-(S)-dimetiloct-2-eno)-imidazólio tetrafluoroborato $\left(\mathrm{MDI}_{-} \mathrm{BF}_{4}\right)$ como eletrólito para produzir hidrogênio por meio eletrólise da água. $\mathrm{O} \mathrm{MDI}-\mathrm{BF}_{4}$ 
sintetizado foi caracterizado por análise termogravimétrica (TG) e calorimetria de exploratória diferencial (DSC), espectroscopia de infravermelho médio com transformada de Fourier pelo método de refletância total atenuada (FTIRATR), espectroscopia de ressonância magnética nuclear de hidrogênio (NMR $\left.{ }^{1} \mathrm{H}\right)$ e voltametria cíclica (CV). Os rendimentos da síntese foram calculados pelo TG e DSC. Dos resultados: A espectroscopia de infravermelho identificou os grupos funcionais do composto e da ligação B-F em $1053 \mathrm{~cm}^{-1}$. O NMR de $1 \mathrm{H}$ analisado e comparado

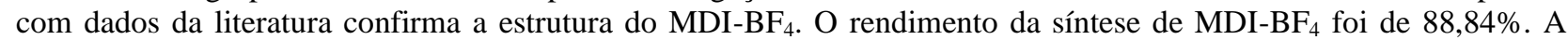
densidade de corrente alcançada pelo $\mathrm{MDI}_{-} \mathrm{BF}_{4}$ no voltamograma mostra que o LI pode conduzir corrente elétrica independente da concentração de água, indicando que o $\mathrm{MDI}_{-} \mathrm{BF}_{4}$ é um eletrólito potencial para produção de hidrogênio a partir da eletrólise da água.

Palavras-chave: Líquidos iônicos; Tetrafluoroborato; 1-Metilimidazol; Rendimento da reação; Água; Eletrólise.

\section{Resumen}

Los líquidos iónicos (IL) son buenos conductores eléctricos y compuestos líquidos orgánicos a temperatura ambiente, con aplicabilidad potencial en la electrólisis del agua para la generación de $\mathrm{H}_{2}$. El propósito de este trabajo es describir la síntesis, caracterización y estudio de la viabilidad del líquido iónico 1-metil-3-(2,6-(S)-dimetiloct-2-eno)-imidazolio tetrafluoroborato $\left(\mathrm{MDI}_{-} \mathrm{BF}_{4}\right)$ como electrolito para producir hidrógeno mediante de la electrólisis del agua. El MDI$\mathrm{BF}_{4}$ sintetizado se caracterizó por análisis termogravimétrico (TGA) y calorimetría diferencial de barrido (DSC), espectroscopia de infrarrojo medio con transformada de Fourier por método de reflectancia total atenuada (FTIRATR), espectroscopia de resonancia magnética nuclear de hidrógeno (RMN $\left.{ }^{1} \mathrm{H}\right)$ y voltamperometría cíclica (CV). El rendimiento de la síntesis se calculados por TGA y DSC. De los resultados: La espectroscopía infrarroja identificó los grupos funcionales del compuesto y el enlace B-F a $1053 \mathrm{~cm}^{-1}$. La RMN ${ }^{1} \mathrm{H}$ analizada y comparada con los datos de la literatura confirma la estructura de $\mathrm{MDI}_{-} \mathrm{BF}_{4}$. El rendimiento de la síntesis de MDI-BF 4 que fue del $88,84 \%$. La densidad de corriente alcanzada por $\mathrm{MDI}_{-} \mathrm{BF}_{4}$ en el voltamograma muestra que el IL puede conducir corriente eléctrica independientemente de la concentración de agua, lo que indica que $\mathrm{MDI}-\mathrm{BF}_{4}$ es un electrolito potencial para la producción de hidrógeno a partir de la electrólisis del agua.

Palabras clave: Líquido iónico; Tetrafluoroborato; 1-Metilimidazol; Rendimiento de la reacción; Agua; Electrólisis.

\section{Introdução}

Ionic liquids have become increasingly popular as a reactive medium for chemical synthesis as well as they have been widely promoted as 'green solvents', which are considered powerful alternatives to the volatile organic compounds (VOCs) in the organic synthesis field. In addition, the task-specific ionic liquids (TSILs), in which the functional group is covalently bonded to the ionic liquid cation or anion (or both), are the last generation of ILs. The incorporation of this functionality should allow the ionic liquid to work as both medium reaction and reagent or catalyst in certain reactions and processes. Nowadays, the TSILs have been applied in chemical industries and have attracted great interest in many areas of research, specially in organic synthesis, due to economic and ecological reasons (Yue et al., 2011).

Due to their extraordinary characteristics, the ionic liquids are important materials which present applications such as solvents in organic and organometallic synthesis, in catalysis, as electrolytes in electrochemistry, in fuels and photovoltaic cells, as lubricants, as stationary phase for chromatography, as matrices for mass spectrometry, as supports for enzymes and catalysts immobilization, in separation technologies, as liquid crystals, as templates for synthesis of mesoporous materials, nanomaterials and fine films, as materials for embalming and preservation of tissues (Liu \& Yu, 2019; Rola et al., 2019). Their great number of cátions and anions allows the achievement of a wide range of physical and chemical characteristics, including volatile and nonvolatile systems. This allows the control of the reaction processing, as well as the control of the solvent-solute interactions (Zhu et al., 2019).

Ionic liquids have been studied to an increasing extent at room temperature in attempt to make it environmentally 'green'. They present low vapour pressure and limited miscibility with water and organic solvents; which indicates those liquids are, possibly, fully recyclable. The most common ionic liquids are formed by dialkylimidazolium cations and, a voluminous and hydrophobic anion (Babucci \& Uzun, 2016; Baek et al., 2017; Díaz-Rodríguez et al., 2015; Ezzat et al., 2018; Namboodiri \& Varma, 2002; Orsini et al., 2009; Palgunadi et al., 2009; G. Wang et al., 2016; Y. Wang et al., 2014; Xiao et al., 2010; Yan et al., 2015; Zec et al., 2018; Zicmanis \& Anteina, 2014). These solvents are relatively inert and tolerate a large 
variety of chemical substances, but they are generally good for the nucleophilic substitution reaction. In addition, the salts have a polar nature (Liang et al., 2010). The present work has as objective the synthesis, characterization and study of the viability of the 1-methyl-3-(2,6-(S)-dimethyloct-2-ene)-imidazol tetrafluoroborate ionic liquid as electrolyte for the hydrogen production through water electrolysis. The reaction yield ware determined by thermal methods (TGA and DSC), infrared characterization, nuclear magnetic resonance of hydrogen, and the study of the viability of the ionic liquid as electrolyte for the hydrogen production through water electrolysis by cyclic voltammetry.

\section{Metodologia}

Materials used: 8-bromo-2,6-dimethyloct-2-ene (219.16 g. $\mathrm{mol}^{-1}$, $95.0 \%$, Sigma Aldrich); 1-methylimidazole (82.10 $\mathrm{g} \cdot \mathrm{mol}^{-1}, 99.0 \%$, Sigma Aldrich); acetonitrile (41.05 g $\cdot \mathrm{mol}^{-1}, 99.9 \%$, Sigma Aldrich); sodium tetrafluoroborate (109.79 $\mathrm{g} \cdot \mathrm{mol}^{-}$ ${ }^{1}, 98.0 \%$, Sigma Aldrich) and acetone (58.08 $\mathrm{g} \cdot \mathrm{mol}^{-1}, 99.5 \%$, Sigma Aldrich).

The 1-methyl-3-(2,6-(S)-dimethyloct-2-ene)-imidazolium bromide was prepared by the reaction between 8-bromo2,6-dimethyloct-2-ene ( $20 \mathrm{~mL}, 96.2 \mathrm{mmol})$ and 1-methylimidazole ( $8.563 \mathrm{~g}, 97.17 \mathrm{mmol}$ ) dissolved in $40 \mathrm{~mL}$ of acetonitrile in a $100 \mathrm{~mL}$ round-bottom balloon coupled to a reflux condenser. The system ware kept under magnetic stirring and heating at 50 ${ }^{\circ} \mathrm{C}$ for $24 \mathrm{~h}$. The resulting viscous mixture was taken to a Rotary evaporator (model $826 \mathrm{~T}$ ), at 200 rotations per minute, $50{ }^{\circ} \mathrm{C}$, $-100 \mathrm{mmHg}$ pressure for $4 \mathrm{~h}$ in order to remove the volatile components, with final achievement of a yellowish, viscous, concentrated liquid. The methodology of this synthesis follows the proceedings used by (Wadhawan et al., 2000).

The 1-methyl-3-(2,6-(S)-dimethyloct-2-ene)-imidazolium tetrafluoroborate was obtained by the reaction between sodium tetrafluoroborate $(9.943 \mathrm{~g}, 90.6 \mathrm{mmol})$ and 1-methyl-3-(2,6-(S)-dimethyloct-2-ene)-imidazolium bromide (26.966 g, $88.7 \mathrm{mmol}$ ), which were diluted in $40 \mathrm{~mL}$ of acetone. After $24 \mathrm{~h}$ of stirring at room temperature, the sodium bromide was removed by filtration and the solution was concentrated in a Rotary evaporator (model $826 \mathrm{~T}$ ), at 200 rotations per minute, 50 ${ }^{\circ} \mathrm{C},-100 \mathrm{mmHg}$ pressure for $4 \mathrm{~h}$, for the removal of volatile compounds.

The thermogravimetric curves were performed in a TA instruments Q600 equipment up to $900{ }^{\circ} \mathrm{C}$ for solid state samples and up to $350{ }^{\circ} \mathrm{C}$ for liquid state samples (flow rate of $100 \mathrm{~mL} \cdot \mathrm{min}^{-1}$ of $\mathrm{N}_{2}$ and heating ramp of $5{ }^{\circ} \mathrm{C} \cdot \mathrm{min}^{-1}$ ). The reaction yield was calculated based the thermogravimetric curves through the Eq. (1).

$$
R=\left(\frac{p m \cdot M D I-B R 1}{p m \cdot M D I-B r 2}\right) * 100 \%
$$

Where: $\mathrm{R}$ is the yield of the reaction; $\mathrm{pm} \mathrm{MDI}-\mathrm{Br} 1$ is the mass percentage of MDI- $\mathrm{Br}$ and $\mathrm{pm} \mathrm{MDI}-\mathrm{Br} 2$ is the mass percentage considering the MDI-Br and part of the reagents that did not react. The ionic liquid's mid-infrared absorption spectrum were obtained in a Spectrum 65 FT-IR spectrometer (Perkin Elmer) with scans ranging from $4000 \mathrm{~cm}^{-1}$ to $650 \mathrm{~cm}^{-1}$. The spectra of nuclear magnetic resonance of hydrogen were obtained from Avance DPX-500 spectrometers (Bruker) using a 5 $\mathrm{mm}$ direct detection dual probe. The samples were dissolved in quotes of $0.6 \mathrm{~mL}$ of deuterated chloroform solvent $\left(\mathrm{CDCl}_{3}\right)$ from Tedia Brazil. The chemical shifts (d) were expressed in parts per million (ppm). The multiplicities of the hydrogen signals on the RMN ${ }^{1} \mathrm{H}$ spectrum was indicated according to the convention: s (singlet), $\mathrm{d}$ (duplet), t (triplet), $\mathrm{m}$ (multiplet).

The cyclic voltammetry proceeded in a glass cell, with $-1.2 \mathrm{~V}$ initial potential, anodic direction, $0.1 \mathrm{~V} \mathrm{~s}^{-1}$ scanning speed, $1.6 \mathrm{~V}$ inversion potential, where the scanning continued on the cathodic direction until it reached $-1.2 \mathrm{~V}$. The voltammogram was obtained with boron-doped diamond working electrode with $0.20589 \mathrm{~cm}^{2}$ geometric area, Calomel reference electrode, and platinum counter electrode. Voltammograms were obtained for pure $\mathrm{MDI}-\mathrm{BF}_{4}$, and for $\mathrm{MDI}_{-}-\mathrm{BF}_{4}$ containing 3 and $7 \%$ of deionized water. The experiment was realized in duplicate, and a PGSTAT $302 \mathrm{~N}$ potenciostastgalvanostat (Autolab) was employed. 


\section{Results and Discussion}

The production of MDI-Br occurs in a single step reaction as seen in Figure 1A, characterized by a bimolecular nucleophilic substitution $\left(\mathrm{S}_{\mathrm{N}} 2\right)$ where the nitrogen of the secondary amine acts as a nucleophile attacking the carbon alpha, leading to the release of the bromide. The formation of the $\mathrm{N}-\mathrm{C}$ bond occurs at the same time as the $\mathrm{C}$-Br Bond cleaves. On the $\mathrm{MDI}-\mathrm{BF}_{4}$ synthesis, the reaction is also $\mathrm{S}_{\mathrm{N}}$ 2-type; however in this case, a simple exchange reaction takes place, where the organic chain (specifically the imidazole ring) presents electropositive character and the anion $\mathrm{Br}$ - is substituted by $\mathrm{BF}_{4}-\mathrm{due}_{\mathrm{s}}$ its more electronegative character, forming the 1-methyl-3-(2,6-(S)-dimethyloct-2-ene)-imidazolium tetrafluoroborate.

After the synthesis, the MDI-Br was analysed by TGA and DSC techniques, in order to obtain the reaction yield. Figure 1B shows the TGA curve, which indicates only one event of mass loss, however when the DSC curve is analysed (Figure 1B), it is observed that the thermal decomposition of MDI-Br occurred in four stages. The first stage of mass loss (between $30-76^{\circ} \mathrm{C}$ ) is associated to the evaporation of acetonitrile, the solvent used on the reaction, which represents $4 \%$ of the material even after the vacuum evaporation. The second stage (between $76-117^{\circ} \mathrm{C}$ ) corresponds to the excess of 8 -bromo2,6-dimethyloct-2-ene that did not react with the 1-methylimidazole and was present in $2.40 \%$ of the mass of MDI-Br. The third stage (between $117-170^{\circ} \mathrm{C}$ ) corresponds to the evaporation of the 1-methylimidazole that did not react and was present in $1.43 \%$. At last, the fourth stage, between 170 and $193{ }^{\circ} \mathrm{C}$, corresponds to the 1-methyl-3-(2,6-(S)-dimethyloct-2-ene)imidazolium bromide formed and is present in $92.15 \%$ of the mass composition of MDI-Br. The reaction yield was calculated based on the Eq. (1) which accounts only for the mass percentage of reagents and products; this calculus is done neglecting the solvent mass ( $\mathrm{R}$ is the yield of the reaction which was $96.01 \%$ ). The value $92.15 \%$ is the mass percentage of $\mathrm{MDI}-\mathrm{Br}$ (pm MDI-Br 1), $95.98 \%$ is the mass percentage considering the MDI-Br and part of the reagents that did not react (pm MDI-Br 2).

The previously described mass loss stages were defined from the study shown in Figure 1C, where it can be see the profile of thermal degradation curves of each reagent used in the synthesis of MDI-Br and of the solvent (acetonitrile). As expected, since the acetonitrile is a solvent with low boiling temperature, it evaporated completely before $60{ }^{\circ} \mathrm{C}$. The 8 -bromo2,6-dimethyloct-2-ene fully volatilized in a temperature lower than $150{ }^{\circ} \mathrm{C}$ and the 1-methyloct-2-ene fully volatilized in a temperature inferior to $170{ }^{\circ} \mathrm{C}$. The minimum shift of the DSC curve among Figure $1 \mathrm{~B}$ and $\mathrm{C}$ is due to the intermolecular nteractions between solvent, reagents and products. 
Figure 1 - A) Reaction of production of MDI-Br. B) Thermal analysis of MDI-Br (TGA and DSC). C) Thermal analysis of the reagents (8-bromo-2,6-dimethyl-2-octane and 1-methylimidazole) for the production of MDI-Br, and of the solvent (acetronitile) used onthe synthesis.
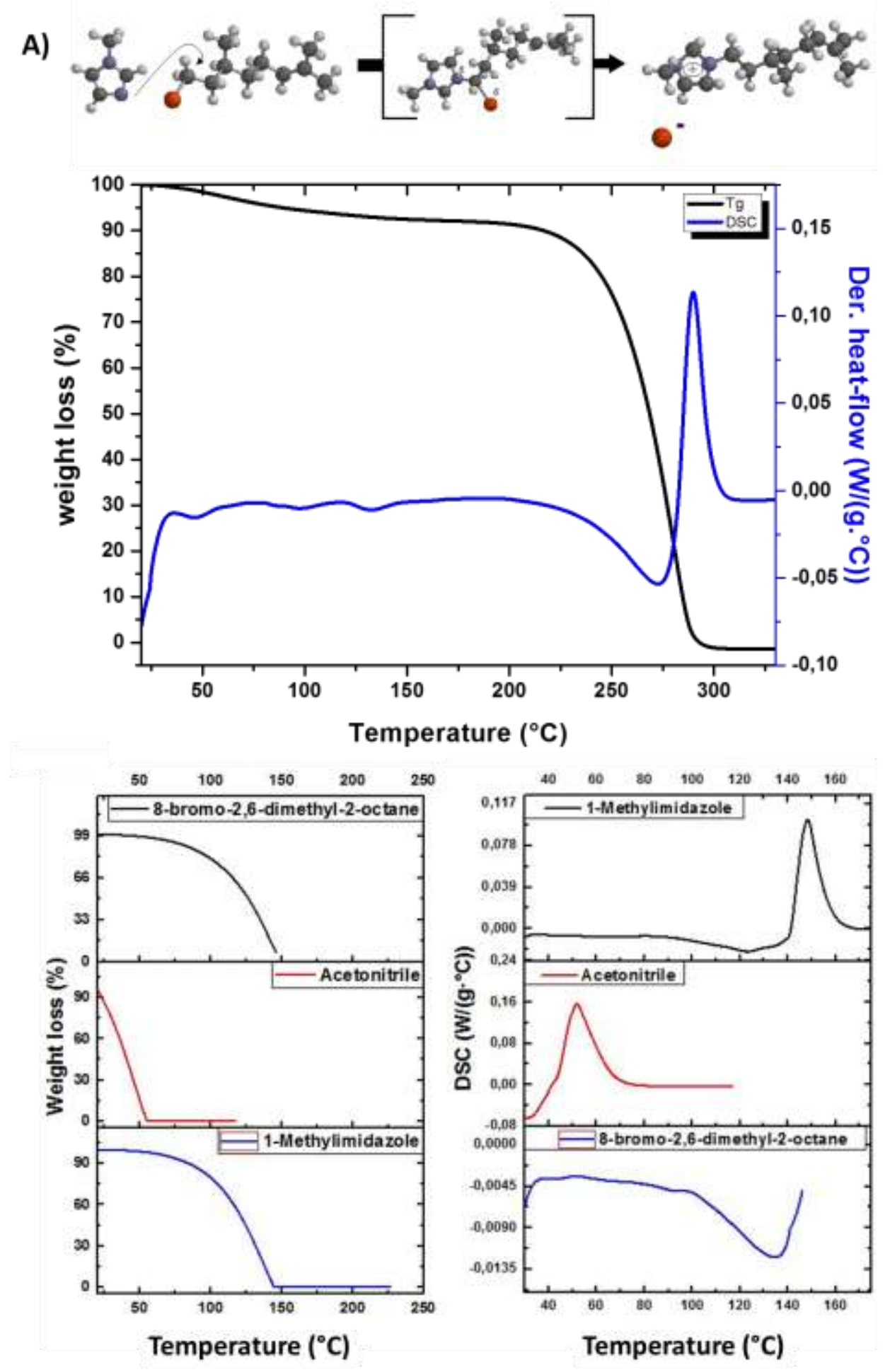

Source: Research data (2021).

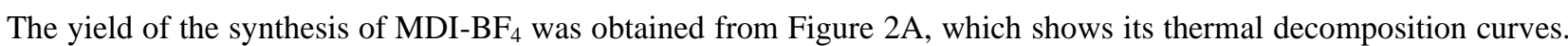
The event between 180 and $460{ }^{\circ} \mathrm{C}$ on the TGA profile corresponds to the percentage of MDI-BF 4 formed; the previous events correspond to reagents that did not react and follow the same logics applied to the yield of MDI-Br, but here the yield is 
represented based on the total mass of the sample. The achieved yield was $88.84 \%$. Figure $2 \mathrm{~B}$ shows the profiles of thermal degradation curves of each reagent used in the synthesis of $\mathrm{MDI}_{-} \mathrm{BF}_{4}$ and of the solvent (propanone). The first mass loss event occurred at a temperature lower than $60{ }^{\circ} \mathrm{C}$, corresponding to the evaporation of propanone (solvent); while the two events between 125 and $175{ }^{\circ} \mathrm{C}$ refer to residues (1-methylimidazole and 8-bromo-2,6-dimethyloct-2-ene) from the synthesis of MDI$\mathrm{Br}$. The DSC curve of MDI-BF 4 (Figure 1B) shows no evidence of decomposition of $\mathrm{NaBF}_{4}$, indicating that virtually all the $\mathrm{NaBF}_{4}$ was consumed or that parto $\mathrm{f}$ unreacted $\mathrm{NaBF}_{4}$ were retained on the filtration. The DSC curve also shows no evidence of thermal decomposition of $\mathrm{NaBr}$, which only occurs at higher temperatures. However, it was observed that TGA curve of $\mathrm{NaBr}$ does not achieve the mass percentage of 0 , revealing that part of the $\mathrm{NaBr}$ (subproduct of $\mathrm{MDI}_{-} \mathrm{BF}_{4}$ synthesis) was either not well filtered, or part of it was dissociated, crossing the filter along with the desired product.

Figure 2 - A) Thermal analysis of $\mathrm{MDI}^{-\mathrm{BF}_{4}}$ (TGA and DSC). B) Thermal analysis of sodium bromide, sodium tetrafluoroborate and of the solvent (propanone) used on the synthesis of MDI-BF4.
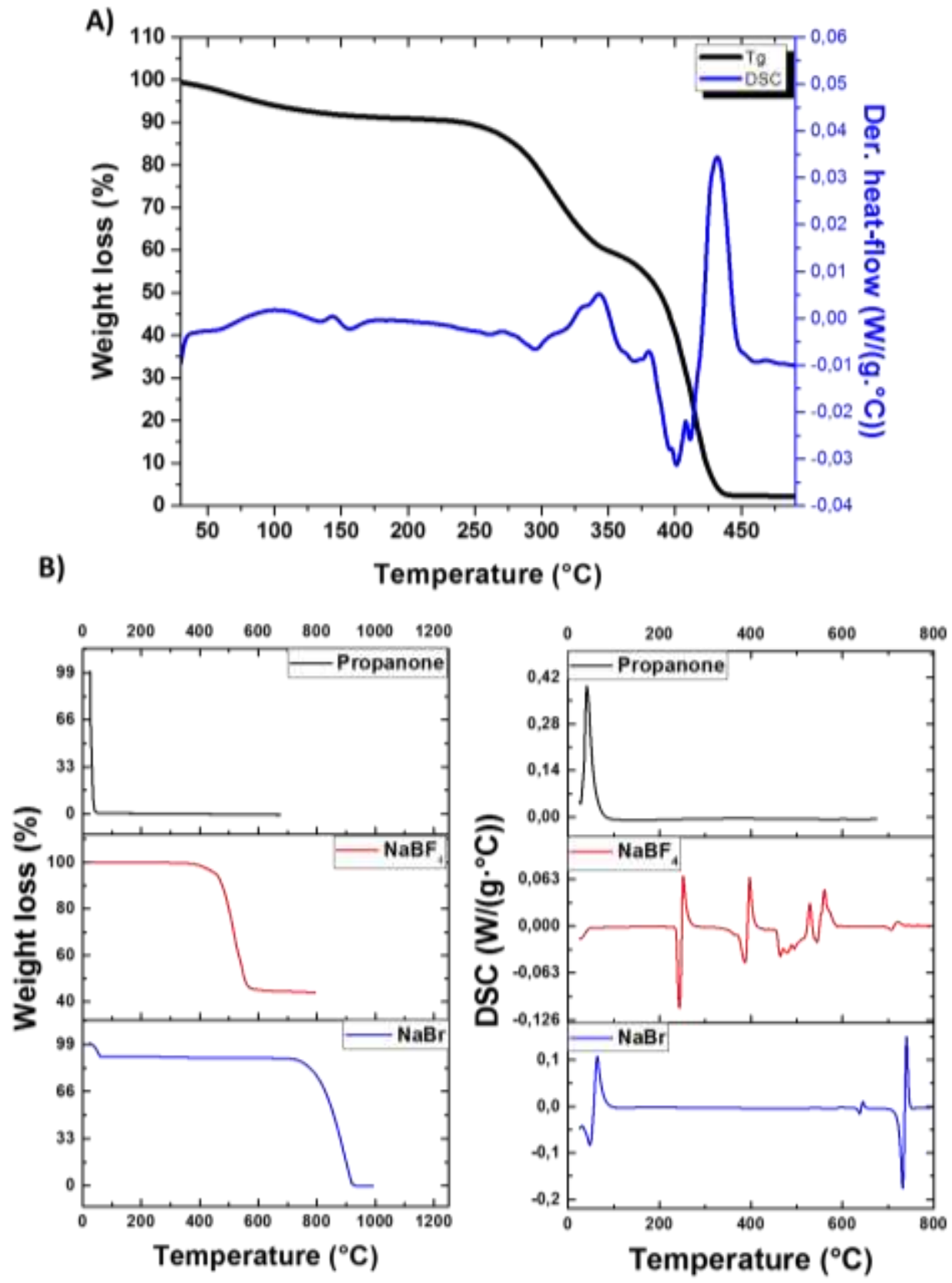

Source: Research data (2021). 
Figure 3A presents the vibrational spectrum of 1-methylimidazol. The spectrum presents bands characteristic of this compound, as the ones at 650 to $1700 \mathrm{~cm}^{-1}$, referents to the axial deformation vibrations of the imidazol ring's bonds. The peaks between 1200 and $1700 \mathrm{~cm}^{-1}$ correspond to the axial deformations of the bonds $\mathrm{C}=\mathrm{C}, \mathrm{C}-\mathrm{N}$ and $\mathrm{C}=\mathrm{N}$ of the ring. The peak at $1420 \mathrm{~cm}^{-1}$ is associated to the $\mathrm{C}=\mathrm{N}$ bond; the peak at $1285 \mathrm{~cm}^{-1}$ refers to the $\mathrm{C}-\mathrm{N}$ bond of aromatics, and the peak at $1230 \mathrm{~cm}^{-1}$ to $\mathrm{C}-\mathrm{N}$ of aliphatics. At $3108 \mathrm{~cm}^{-1}$ the $\mathrm{C}-\mathrm{H}$ band of alkenes is observed. Figure 3B shows the vibrational spectrum of 8-bromo-2,6-dimethyloct-2-ene. The bands at 2964, 2915 and $2871 \mathrm{~cm}^{-1}$ refer to the primary, secondary and tertiary carbon of the $\mathrm{C}-\mathrm{H}$ bond of aliphatics, respectively. The peak at $1450 \mathrm{~cm}^{-1}$ refers to the axial deformation of the $\mathrm{C}=\mathrm{C}$ bond, and the peak at $1375 \mathrm{~cm}^{-1}$ refers to the angular deformation of $-\mathrm{CH}_{3}$ (Small, 1992).

Figure $3 \mathrm{C}$ indicates that $\mathrm{MDI}-\mathrm{Br}$ is succefully obtained from the proposed method, in which the peaks between 3141 $3069 \mathrm{~cm}^{-1}$ refer to the $\mathrm{C}-\mathrm{H}$ bond of aromatics, and the peaks at 2961, 2914 and $2854 \mathrm{~cm}^{-1}$ correspond to the C-H bond of aliphatics; similar values were found by (Wadhawan et al., 2000). The peaks at 1571 and $1452 \mathrm{~cm}^{-1}$ refer to the axial deformation of $\mathrm{C}=\mathrm{C}$; the peak at $1378 \mathrm{~cm}^{-1}$ refers to the $\mathrm{C}-\mathrm{N}$ bond of aromatics, and the peak at $1168 \mathrm{~cm}^{-1}$ to the $\mathrm{C}-\mathrm{N}$ bond of aliphatics; whereas the peaks at 830 and $755 \mathrm{~cm}^{-1}$ refer to the $\mathrm{CH}$ out of the plane of the group $\mathrm{RCH}=\mathrm{CR}_{2}$. The $\mathrm{NaBF}_{4}$ used in this study was also analysed by infrared spectroscopy to find out in what region of the spectrum the interaction between fluorine and boron appears. Its spectrum is presented in Figure 3D, presenting only one peak at $1011 \mathrm{~cm}^{-1}$, which corresponds to the interactions of the four fluorines and the boron.

Infrared spectrum of MDI-BF 4 is depicted in Figure $3 \mathrm{E}$ and the peaks betwenn $3158-3118 \mathrm{~cm}^{-1}$ refer to the C-H bond of aromatics; the ones at 2964, 2916 and $2856 \mathrm{~cm}^{-1}$ correspond to the $\mathrm{C}-\mathrm{H}$ bond of aliphatics, and the peaks at 1574 and 1452 $\mathrm{cm}^{-1}$ are related to the axial deformation of the $\mathrm{C}=\mathrm{C}$ bond. Whereas, the peak at $1378 \mathrm{~cm}^{-1}$ refers to the $\mathrm{C}-\mathrm{N}$ bond of aromatics, and the peak at $1169 \mathrm{~cm}^{-1}$ refers to the $\mathrm{C}-\mathrm{N}$ of aliphatics; the peaks at 845 and $762 \mathrm{~cm}^{-1}$ refer to the $\mathrm{C}-\mathrm{H}$ out of the plane of the group RCH-CR 2 , and the peak at 1053 corresponds to the B-F bond. 
Figure 3 - Mid-infrared spectra of: A) 1-methylimidazole; B) 8-bromo-2,6-dimethyloct-2-ene; C) MDI-Br; D) sodium tetrafluoroborate; E) MDI-BF 4 .
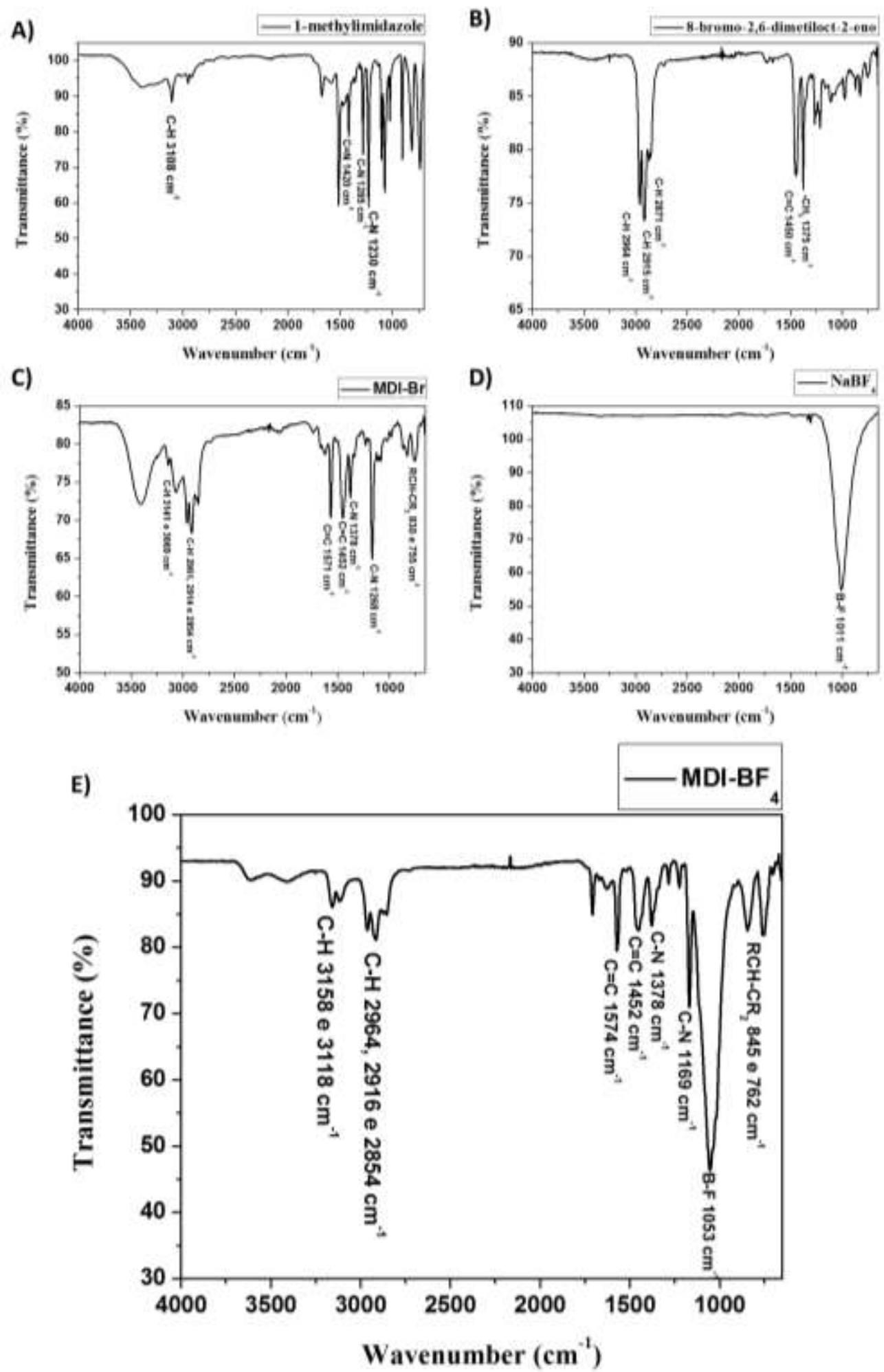

Source: Research data (2021).

In the $\mathrm{RMN}{ }^{1} \mathrm{H}$ spectrum of $\mathrm{MDI}-\mathrm{BF}_{4}$ (Figure 4A), characteristic aromatic hydrogen signals of the imidazole ring appear between 7.0 and $9.0 \mathrm{ppm}$, where the singlets at 8.91, 7.42 and $7.32 \mathrm{ppm}$ correspond to the hydrogens $\mathrm{H} 2$, $\mathrm{H} 4$ and $\mathrm{H} 5$, respectively. In the same spectrum, singlets observed at $\delta 3.93,1.63$ and $0.93 \mathrm{ppm}$, are characteristic of methylic hydrogen of 
the lateral chain derived from the 8-bromo-2,6-dimethyloct-2-ene. The other hydrogens of this aliphatic chain appear concentrated on the region between $\delta 1.0$ and $5.1 \mathrm{ppm}$; a triplet signal at $\delta 5.02 \mathrm{ppm}$ is characteristic of non conjugated Double bond corresponding to H12; a multiplet signal at $\delta 4.18 \mathrm{ppm}$ corresponds to $\mathrm{H} 7$; a multiplet signal at $\delta 1.93 \mathrm{ppm}$ corresponds to $\mathrm{H} 9$ and $\mathrm{H} 11$; multiplets signals at 1.67 and $1.46 \mathrm{ppm}$ corresponding to $\mathrm{H} 8$; and multiplets signals at 1.32 and $1.24 \mathrm{ppm}$ are referent to H10. From the analysed results, as well as for comparison with literature (Liu \& Yu, 2019; Wadhawan et al., 2000) as shown in Table 1, it is possible to confirm the formation of the 1-methyl-3-(2,6-(S)-dimethyloct-2-ene)-imidazolium tetrafluoroborate.

Table 1 - RMN ${ }^{1} \mathrm{H}$ data for the compound MDI-BF 4 in comparison with literature data in $\mathrm{CDCl}_{3}$.

\begin{tabular}{cc}
\hline MDI-BF $_{4}$ & Literature $^{\mathrm{a}}$ \\
\hline $8.91(\mathrm{~s}, 1 \mathrm{H}, \mathrm{H} 2)$ & $9.09(\mathrm{~s}, 1 \mathrm{H}, \mathrm{H} 2)$ \\
$7.42(\mathrm{~s}, 1 \mathrm{H}, \mathrm{H} 4)$ & $7.46(\mathrm{~s}, 1 \mathrm{H}, \mathrm{H} 4)$ \\
$7.32(\mathrm{~s}, 1 \mathrm{H}, \mathrm{H} 5)$ & $7.36(\mathrm{~s}, 1 \mathrm{H}, \mathrm{H} 5)$ \\
$5.02(\mathrm{t}, 1 \mathrm{H}, \mathrm{H} 12)$ & $5.04(\mathrm{t}, 1 \mathrm{H}, \mathrm{H} 12)$ \\
$4.18(\mathrm{~m}, 2 \mathrm{H}, \mathrm{H} 7)$ & $4.19(\mathrm{~m}, 2 \mathrm{H}, \mathrm{H} 7)$ \\
$3.93(\mathrm{~s}, 3 \mathrm{H}, \mathrm{H} 6)$ & $3.97(\mathrm{~s}, 3 \mathrm{H}, \mathrm{H} 6)$ \\
$1.93(\mathrm{~m}, 2 \mathrm{H}, \mathrm{H} 11)$ & $1.96(\mathrm{~m}, 2 \mathrm{H}, \mathrm{H} 11)$ \\
$1.93(\mathrm{~m}, 2 \mathrm{H}, \mathrm{H} 9)$ & $1.96(\mathrm{~m}, 1 \mathrm{H}, \mathrm{H} 9)$ \\
$1.67(\mathrm{~m}, 2 \mathrm{H}, \mathrm{H} 8)$ & $1.71(\mathrm{~m}, 2 \mathrm{H}, \mathrm{H} 8)$ \\
$1.63(\mathrm{~s}, 3 \mathrm{H}, \mathrm{H} 14)$ & $1.65(\mathrm{~s}, 3 \mathrm{H}, \mathrm{H} 14)$ \\
$1.55(\mathrm{~s}, 3 \mathrm{H}, \mathrm{H} 15)$ & $1.58(\mathrm{~s}, 3 \mathrm{H}, \mathrm{H} 15)$ \\
$1.46(\mathrm{~m}, 2 \mathrm{H}, \mathrm{H} 8)$ & $1.48(\mathrm{~m}, 2 \mathrm{H}, \mathrm{H} 8)$ \\
$1.32(\mathrm{~m}, 2 \mathrm{H}, \mathrm{H} 10)$ & $1.36(\mathrm{~m}, 2 \mathrm{H}, \mathrm{H} 10)$ \\
$1.24(\mathrm{~m}, 2 \mathrm{H}, \mathrm{H} 10)$ & $1.22(\mathrm{~m}, 2 \mathrm{H}, \mathrm{H} 10)$ \\
$0.93(\mathrm{~d}, 3 \mathrm{H}, \mathrm{H} 16)$ & $0.95(\mathrm{~d}, 3 \mathrm{H}, \mathrm{H} 16)$ \\
\hline
\end{tabular}

Source: adapted from ${ }^{\mathrm{a}}$ (Wadhawan et al., 2000).

The cyclic voltammetry technique is used to determine the electrochemical window of stability of compounds, in other words, the potential range that could be applied without the decomposition of the IL on the surface of an electrode. In this work, the MDI-BF 4 was analysed pure and in aqueous solution, in order to study the influence of water addition on the IL. Figure $4 \mathrm{~B}$ shows the cyclic voltammograms of $\mathrm{MDI}-\mathrm{BF}_{4}$ pure and with additions of 3 and 7 vol. \% of deionized water. It is possible to observe that there is no relevant signal of a redox system for the pure ionic liquid MDI-BF 4 . However, when water was introduced in the system, the current densities observed at $+1.5 \mathrm{~V}$ (potential near the oxidation of water molecule $2 \mathrm{H}_{2} \mathrm{O}_{(\mathrm{l})}$ $\left.\rightarrow \mathrm{O}_{2(\mathrm{~g})}+4 \mathrm{H}_{(\mathrm{g})}+4 \mathrm{e}^{-}\right)$did not rise exponentially. This happens because the concentration of water in the system does not favor the molecule oxidation at these potentials, albeit the IL was used. 


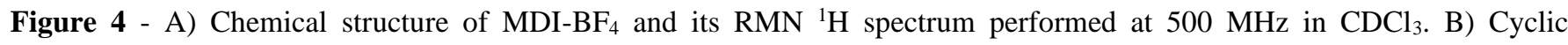

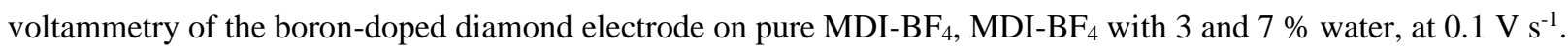

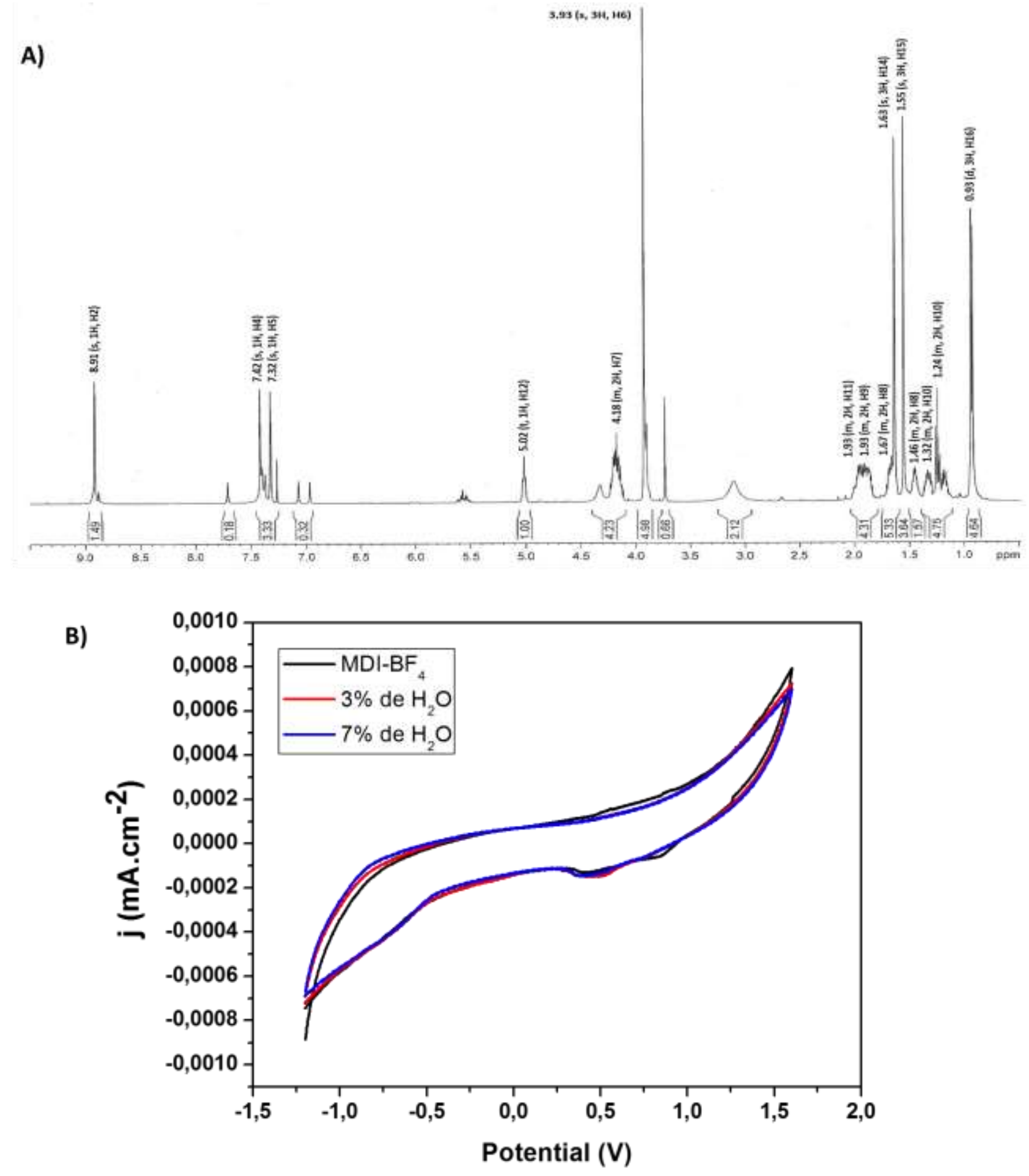

Source: Research data (2021).

When the cathodic scannings are performed, the exponential rise of the current densities at $-1.2 \mathrm{~V}$ does not evidence a notable $\mathrm{H}_{2}$ (g) production. The same behavior was observed when the water concentration in the system rose from $3 \% \mathrm{~V} / \mathrm{V}$ to $7 \% \mathrm{~V} / \mathrm{V}$. From these effects, it is inferred that the IL is an electrolyte capable of conducting electrical current in a potential window of $2.4 \mathrm{~V}$ without structural alterations (due to the non-observation of anodic or cathodic peaks referring to the 
decomposition of the IL). Likewise, the IL has a similar behavior amid different concentrations of water in the system, promoting no alteration in its voltammetric profile.

\section{Conclusion}

From the results obtained, it was possible to conclude that: the thermogravimetric techniques (TGA/DSC) were very effective for quantification of the reagents and products present on the synthesis of MDI-Br and MDI-BF 4 , as well as the quantification of the solvent, which remained in low concentration even after the solution was submitted to evaporation at low pressure and at $50{ }^{\circ} \mathrm{C}$. The thermal degradations of each component were observed thanks to the use of the DSC technique simultaneously to the TGA. From the infrared spectroscopy, it was possible to confirm some organic functions of the structure, and the presence of the tetrafluoroborate on the $\mathrm{MDI}-\mathrm{BF}_{4}$ chain after its synthesis, whereas the organic structure only could be confirmed with the RMN ${ }^{1} \mathrm{H}$ spectroscopy and comparison with the data in literature. It is concluded that 1-methyl-3-(2,6-(S)dimethyloct-2-ene)-imidazolium tetrafluoroborate was obtained with $88.8 \%$ purity. The current density achieved by the MDI$\mathrm{BF}_{4}$ on the voltammogram (under the experimental conditions described in this work) shows that the IL can conduct electrical current, indicating that the MDI-BF 4 is a good electrolyte, and its behaviour does not alter with increasing water concentration. In addition, the voltammetric tests evidenced a plausible use of the IL in experiments that involve the passage of current, presenting an optimum performance for the conditions adopted in this work. Finally, the authors suggest obtaining modified electrodes with $\mathrm{MDI}-\mathrm{BF}_{4}$, and this modification should be investigat using electrochemical techniques. In addition, it would be very interesting to repeat the synthesis using commercial citronella oil in order to carry out a comparative study between the results obtained in the present work.

\section{Acknowledgments}

This study was financed in part by the Coordenação de Aperfeiçoamento de Pessoal de Nível Superior - Brasil (CAPES) - Finance code 001. The authors acknowledge the CAPES, ANEEL and Petrobrás for the financial support used on the performance this work, the Dennis R. A. B. Lima and the entire team of the Environmental Technology Laboratory (LABTAM).

\section{References}

Babucci, M., \& Uzun, A. (2016). Effects of interionic interactions in 1,3-dialkylimidazolium ionic liquids on the electronic structure of metal sites in solid catalysts with ionic liquid layer (SCILL). Journal of Molecular Liquids, 216, 293-297. https://doi.org/10.1016/j.molliq.2015.12.074

Baek, C. S., Lee, Y. J., Lee, S. J., Lee, S. G., Kim, H. C., \& Jeong, S. W. (2017). C2-Functionalized 1,3-dialkylimidazolium ionic liquids for efficient cellulose dissolution. Journal of Molecular Liquids, 234, 111-116. https://doi.org/10.1016/j.molliq.2017.03.086

Díaz-Rodríguez, P., Cancilla, J. C., Matute, G., Chicharro, D., \& Torrecilla, J. S. (2015). Inputting molecular weights into a multilayer perceptron to estimate refractive indices of dialkylimidazolium-based ionic liquids - A purity evaluation. Applied Soft Computing Journal, 28, 394-399. https://doi.org/10.1016/j.asoc.2014.12.004

Ezzat, A. O., Atta, A. M., Al-Lohedan, H. A., \& Hashem, A. I. (2018). Synthesis and application of new surface active poly (ionic liquids) based on 1,3dialkylimidazolium as demulsifiers for heavy petroleum crude oil emulsions. Journal of Molecular Liquids, 251, 201-211. https://doi.org/10.1016/j.molliq.2017.12.081

Liang, R., Yang, M., \& Xuan, X. (2010). Thermal stability and thermal decomposition kinetics of 1-butyl-3-methylimidazolium dicyanamide. Chinese Journal of Chemical Engineering, 18(5), 736-741. https://doi.org/10.1016/S1004-9541(09)60122-1

Liu, H., \& Yu, H. (2019). Ionic liquids for electrochemical energy storage devices applications. Journal of Materials Science and Technology, 35(4), 674-686. https://doi.org/10.1016/j.jmst.2018.10.007

Namboodiri, V. V., \& Varma, R. S. (2002). An improved preparation of 1,3-dialkylimidazolium tetrafluoroborate ionic liquids using microwaves. Tetrahedron Letters, 43(31), 5381-5383. https://doi.org/10.1016/S0040-4039(02)01075-4

Orsini, M., Chiarotto, I., Elinson, M. N., Sotgiu, G., \& Inesi, A. (2009). Benzoin condensation in 1,3-dialkylimidazolium ionic liquids via electrochemical 
Research, Society and Development, v. 10, n. 10, e393101018988, 2021

(CC BY 4.0) | ISSN 2525-3409 | DOI: http://dx.doi.org/10.33448/rsd-v10i10.18988

generation of N-heterocyclic carbene. Electrochemistry Communications, 11(5), 1013-1017. https://doi.org/10.1016/j.elecom.2009.02.045

Palgunadi, J., Kang, J. E., Nguyen, D. Q., Kim, J. H., Min, B. K., Lee, S. D., Kim, H., \& Kim, H. S. (2009). Solubility of CO 2 in dialkylimidazolium dialkylphosphate ionic liquids. Thermochimica Acta, 494(1-2), 94-98. https://doi.org/10.1016/j.tca.2009.04.022

Rola, K., Zając, A., Czajkowski, M., Szpecht, A., Zdończyk, M., Śmiglak, M., Cybińska, J., \& Komorowska, K. (2019). Ionic liquids for active photonics components fabrication. Optical Materials, 89(November 2018), 106-111. https://doi.org/10.1016/j.optmat.2019.01.003

Small, G. W. (1992). Spectrometric Identification of Organic Compounds | R.M. Silverstein, G.C. Bassler and T.C. Morrill, 5th edn., Wiley, New York, 1991 (ISBN 0-471-63404-2). 419 pp. Vibrational Spectroscopy, 4(1), 123-124. https://www.sciencedirect.com/science/article/abs/pii/092420319287024A

Wadhawan, J. D., Schröder, U., Neudeck, A., Wilkins, S. J., Compton, R. G., Marken, F., Consorti, C. S., De Souza, R. F., \& Dupont, J. (2000). Ionic liquid modified electrodes. Unusual partitioning and diffusion effects of $\mathrm{Fe}(\mathrm{CN}) 64-/ 3$ - in droplet and thin layer deposits of 1-methyl-3-(2,6-(S)-dimethylocten-2-yl)imidazolium tetrafluoroborate. Journal of Electroanalytical Chemistry, 493(1-2), 75-83. https://doi.org/10.1016/S0022-0728(00)00308-9

Wang, G., Fang, S., Luo, D., Yang, L., \& Hirano, S. ichi. (2016). Functionalized 1,3-dialkylimidazolium bis(fluorosulfonyl)imide as neat ionic liquid electrolytes for lithium-ion batteries. Electrochemistry Communications, 72, 148-152. https://doi.org/10.1016/j.elecom.2016.09.023

Wang, Y., Wei, L., Li, K., Ma, Y., Ma, N., Ding, S., Wang, L., Zhao, D., Yan, B., Wan, W., Zhang, Q., Wang, X., Wang, J., \& Li, H. (2014). Lignin dissolution in dialkylimidazolium-based ionic liquid-water mixtures. Bioresource Technology, 170, 499-505. https://doi.org/10.1016/j.biortech.2014.08.020

Xiao, C., Wibisono, N., \& Adidharma, H. (2010). Dialkylimidazolium halide ionic liquids as dual function inhibitors for methane hydrate. Chemical Engineering Science, 65(10), 3080-3087. https://doi.org/10.1016/j.ces.2010.01.033

Yan, B., Li, K., Wei, L., Ma, Y., Shao, G., Zhao, D., Wan, W., \& Song, L. (2015). Understanding lignin treatment in dialkylimidazolium-based ionic liquidwater mixtures. Bioresource Technology, 196, 509-517. https://doi.org/10.1016/j.biortech.2015.08.005

Yue, C., Fang, D., Liu, L., \& Yi, T. F. (2011). Synthesis and application of task-specific ionic liquids used as catalysts and/or solvents in organic unit reactions. Journal of Molecular Liquids, 163(3), 99-121. https://doi.org/10.1016/j.molliq.2011.09.001

Zec, N., Vraneš, M., Bešter-Rogač, M., Trtić-Petrović, T., Dimitrijević, A., Čobanov, I., \& Gadžurić, S. (2018). Influence of the alkyl chain length on densities and volumetric properties of 1,3-dialkylimidazolium bromide ionic liquids and their aqueous solutions. Journal of Chemical Thermodynamics, 121, 72-78. https://doi.org/10.1016/j.jct.2018.02.001

Zhu, X., Song, M., Wang, S., \& Dai, S. (2019). Understanding the effect of molecular solvents on the microscopic network of DBU imidazole ionic liquid. Journal of Molecular Liquids, 276, 325-333. https://doi.org/10.1016/j.molliq.2018.11.146

Zicmanis, A., \& Anteina, L. (2014). Dialkylimidazolium dimethyl phosphates as solvents and catalysts for the Knoevenagel condensation reaction. Tetrahedron Letters, 55(12), 2027-2028. https://doi.org/10.1016/j.tetlet.2014.02.035. 